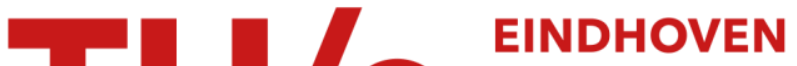 UNIVERSITY OF TECHNOLOGY
}

\section{The texture of diffusion-grown HfAl3 layers}

Citation for published version (APA):

Maas, J. H., Bastin, G. F., Vanloo, F. J. J., \& Metselaar, R. (1983). The texture of diffusion-grown HfAl3 layers. Journal of the Less-Common Metals, 92(1), 111-118. https://doi.org/10.1016/0022-5088(83)90232-1

DOI:

10.1016/0022-5088(83)90232-1

Document status and date:

Published: 01/01/1983

\section{Document Version:}

Publisher's PDF, also known as Version of Record (includes final page, issue and volume numbers)

\section{Please check the document version of this publication:}

- A submitted manuscript is the version of the article upon submission and before peer-review. There can be important differences between the submitted version and the official published version of record. People interested in the research are advised to contact the author for the final version of the publication, or visit the $\mathrm{DOI}$ to the publisher's website.

- The final author version and the galley proof are versions of the publication after peer review.

- The final published version features the final layout of the paper including the volume, issue and page numbers.

Link to publication

\section{General rights}

Copyright and moral rights for the publications made accessible in the public portal are retained by the authors and/or other copyright owners and it is a condition of accessing publications that users recognise and abide by the legal requirements associated with these rights.

- Users may download and print one copy of any publication from the public portal for the purpose of private study or research.

- You may not further distribute the material or use it for any profit-making activity or commercial gain

- You may freely distribute the URL identifying the publication in the public portal.

If the publication is distributed under the terms of Article 25fa of the Dutch Copyright Act, indicated by the "Taverne" license above, please follow below link for the End User Agreement:

www.tue.nl/taverne

Take down policy

If you believe that this document breaches copyright please contact us at:

openaccess@tue.nl

providing details and we will investigate your claim. 


\section{THE TEXTURE OF DIFFUSION-GROWN $\mathrm{HFAl}_{\mathrm{s}}$ LAYERS}

J. H. MAAS, G. F. BASTIN, F. J. J. VAN LOO AND R. METSELAAR

Laboratory for Physical Chemistry, Eindhoven University of Technology, Eindhoven (The Netherlands)

(Received November 12, 1982)

\section{Summary}

$\mathrm{HfAl}_{3}$ layers were grown on hafnium and aluminium substrates. A [001] fan texture was observed in $\mathrm{HfAl}_{3}$ grown by solid state diffusion on textureless hafnium substrates. If layers were grown on a hafnium substrate with a pronounced single-component sheet texture, the texture in the $\mathrm{HfAl}_{3}$ layer was not rotationally symmetric around the direction of diffusion, but a related sheet texture developed. An orientation relation is proposed. Layers grown from the vapour phase on aluminium substrates show an $\langle 841\rangle$ fibre texture.

\section{Introduction}

Little is known about the causes of the development of a texture in diffusion-grown layers of intermetallic compounds. In our laboratory many studies have been performed of both phase diagrams and diffusion kinetics. In a number of systems textures have been observed. This has led to investigations into the relation between the structure of the intermetallic layer and its texture. Further, we have examined the dependence of the texture produced on the substrate and diffusion conditions.

We have previously presented results obtained for diffusion-grown disilicide layers on molybdenum and tungsten [1]; in this paper results will be presented for $\mathrm{HfAl}_{3}$ layers. $\mathrm{HfAl}_{3}$ has a tetragonal unit cell with $a=0.3989 \mathrm{~nm}$ and $c=1.7155 \mathrm{~nm}$.

The experimental procedures which were used for the preparation of the reaction layers and for the subsequent texture investigations are described in Section 2. The experimental results are presented in Section 3 , and a discussion of these results is given in Section 4. 


\section{Experimental details}

Three different techniques were used to produce the $\mathrm{HfAl}_{3}$ layers.

Firstly, use was made of the diffusion couple technique. Al- $\mathrm{Hf}-\mathrm{Al}$ sandwich couples were heated in a vacuum furnace under a load. Although a number of intermetallic compounds exist in the $\mathrm{Hf}-\mathrm{Al}$ system $[2,3]$, only $\mathrm{HfAl}_{3}$ and $\mathrm{HfAl}_{2}$ layers were observed in the solid-solid couples. The $\mathrm{HfAl}_{2}$ layers were very thin even after prolonged annealing. Optical microscopy showed that the contact between the $\mathrm{HfAl}_{2}$ layer and the hafnium substrate was lost, probably owing to differences in thermal expansion.

Secondly, $\mathrm{HfAl}_{3}$ layers were produced by vapour transport in an iodine atmosphere. $\mathrm{HfAl}_{2}$, produced by argon arc melting and subsequent grinding, was heated together with iodine and an aluminium substrate in an evacuated silica capsule at a suitable temperature.

Thirdly, we attempted to produce $\mathrm{HfAl}_{3}$ layers above the melting point of aluminium by using the pack cementation process. A hafnium substrate was heated at 700 or $800^{\circ} \mathrm{C}$ in a closed alumina container. The generator used consisted of a mixture of $\mathrm{Al}_{2} \mathrm{O}_{3}$, aluminium and $\mathrm{CrF}_{2}$ in a mass ratio of 90:20:10. Under these conditions, however, only $\mathrm{HfAl}_{2}$ layers were formed.

The aluminium substrates (purity, $99.99 \%$ ) were obtained from Drijfhout, The Netherlands. Two types of hafnium substrates were used, namely hafnium platelets (Koch-Light, Gt. Britain; purity, $99.9 \%$ including $3.0 \% \mathrm{Zr}$ ) showing a pronounced sheet texture and fine-grained polycrystalline substrates without texture which were produced by argon arc melting.

For the examination of the texture in the reaction layers sections were prepared parallel to the substrate-layer interface.

Pole density measurements were performed using a Philips PW1078 texture goniometer. The measured intensities were corrected for the intensity loss due to defocusing $[4,5]$. Correction curves were obtained by measuring intensities on texture-free powder samples of $\mathrm{HfAl}_{3}$. These samples were made from $\mathrm{HfAl}_{3}$ produced by argon arc melting. After grinding, the sieve fraction below $37 \mu \mathrm{m}$ was pelletized by cold isostatic pressing.

Pole figures were measured using a Siemens texture goniometer with an automatic pole figure plotter [6]. Lücke's method was adopted.

\section{Results}

To investigate the kinetics of the layer formation $\mathrm{Hf}-\mathrm{Al}$ diffusion couples were heated for various times at temperatures of 550,595 and $640{ }^{\circ} \mathrm{C}$. The results are shown in Fig. 1 where it can be seen that the parabolic growth law is not obeyed.

When the iodine transport reaction was used an $\mathrm{HfAl}_{3}$ layer $72 \mu \mathrm{m}$ thick was formed after $28 \mathrm{~h}$ at $640^{\circ} \mathrm{C}$ and a layer $22 \mu \mathrm{m}$ thick was formed after $47 \mathrm{~h}$ at $595^{\circ} \mathrm{C}$. 


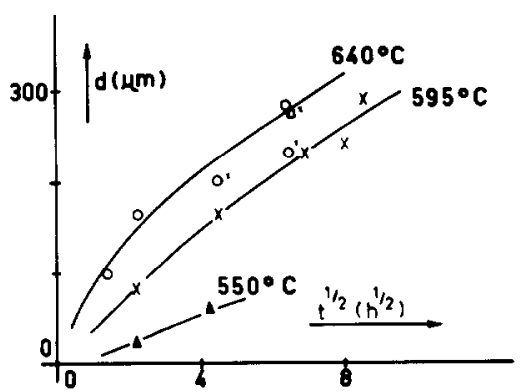

Fig. 1. Layer thickness $v s . t^{1 / 2}$, where $t$ is the time, for $\mathrm{HfAl}_{3}$ layers in $\mathrm{Hf}-\mathrm{Al}$ diffusion couples: $\mathrm{O}, \mathrm{x}$, $\Delta$, layers grown on hafnium with a sheet texture; $\square$, layers grown on textureless hafnium substrates.

\subsection{Texture measurements on the hafnium substrates}

Our first investigation showed the presence of an unusual non-rotationally symmetric texture in the $\mathrm{HfAl}_{3}$ layers grown on the Koch-Light hafnium platelets. Further experiments showed that this texture was related to a texture in the substrate. Therefore we shall first describe the texture observed in these substrates. Before use, the hafnium plate was heated for $24 \mathrm{~h}$ at $640^{\circ} \mathrm{C}$. A pronounced sheet texture was found. The $[11 \overline{2} 0]$ direction was situated approximately in the rolling direction and the normal to the $(0001)$ planes was tilted about $30^{\circ}-35^{\circ}$ with respect to the substrate normal in the transverse direction. Figures 2(a) and 2(b) show the pole figures of the 101 and 0002 reflections respectively. These figures correspond well to those described for hafnium by Wassermann and Grewen [7]. The texture remained unaltered during the formation of the diffusion layers in the temperature region 550 $640^{\circ} \mathrm{C}$.

We also used polycrystalline textureless hafnium to investigate the influence of the substrate texture on the texture of the diffusion layers. For

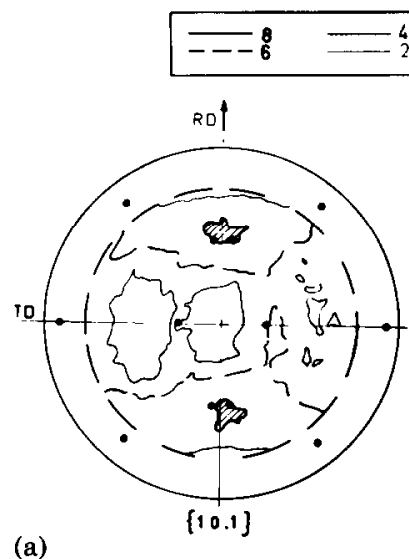

\section{DTI MAXIMUM}
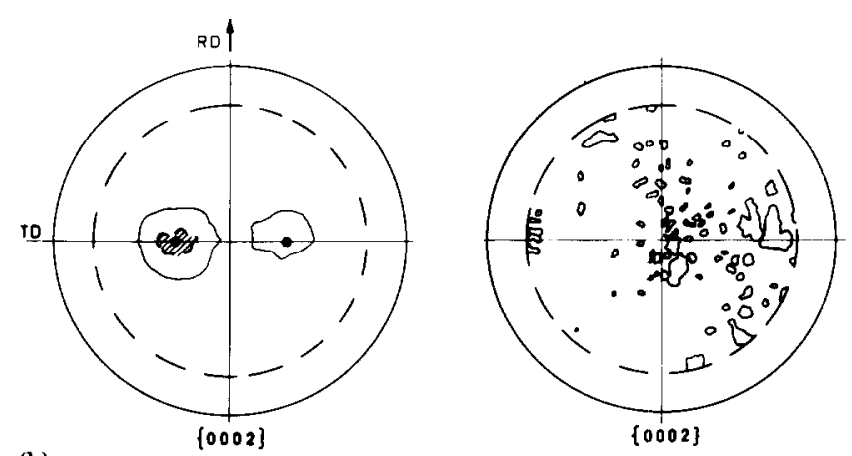

(b)

Fig. 2. Pole figures of hafnium substrates with sheet texture: (a) 101 reflection; (b) 0002 reflection.

Fig. 3. $\{0002\}$ pole figure of the textureless hafnium substrates. 
comparison Fig. 3 shows a pole figure of the 0002 reflection of these substrates.

\subsection{Texture measurements on $\mathrm{HfAl}_{3}$ layers}

$\mathrm{HfAl}_{3}$ grown on textureless hafnium substrates showed a rotationally symmetric texture with respect to the direction of diffusion. From the texture measurements for various reflections the presence of a [001] fan texture could be established. Table 1 gives the measured angles of the maxima with respect to the direction of diffusion. For comparison we also give the positions calculated for a [001] fan texture parallel to the direction of diffusion. The texture sharpness was maximum at the $\mathrm{Hf}-\mathrm{HfAl}_{3}$ interface and gradually diminishes towards the $\mathrm{HfAl}_{3}-\mathrm{Al}$ interface.

TABLE 1

Results of X-ray measurements on $\mathrm{HfAl}_{3}$

\begin{tabular}{llrrr}
\hline$h k l$ & $\begin{array}{l}d \\
(\mathrm{~nm})\end{array}$ & $I / I_{0}{ }^{*}$ & $\begin{array}{c}\chi_{\text {calc }}^{b} \\
(\mathrm{deg})\end{array}$ & $\begin{array}{c}\chi_{\text {mes }}^{b} \\
(\mathrm{deg})\end{array}$ \\
\hline 004 & 0.429 & 32 & 90.0 & $>80$ \\
101 & 0.3885 & 50 & 13.1 & 12 \\
103 & 0.3272 & 24 & 34.9 & 39 \\
110 & 0.2821 & 24 & 0.0 & 0 \\
105 & 0.2601 & 26 & 49.3 & 50 \\
114 & 0.2356 & 100 & 33.3 & 38 \\
008 & 0.2143 & 21 & 90.0 & $>80$ \\
200 & 0.1995 & 33 & 0.0 & 0 \\
211 & 0.1774 & 15 & 5.9 & 0 \\
215 & 0.1583 & 23 & 27.5 & 30 \\
310 & 0.1261 & - & 0.0 & 0 \\
\hline
\end{tabular}

$\chi$ is the tilt angle with respect to the direction of diffusion.

- Mean relative intensities of textureless powder samples.

' $\chi_{\text {catc }}$ and $\chi_{\text {meas }}$ are the calculated and measured values respectively for a [001] fan texture parallel to the diffusion direction. All reflections show a broad maximum, e.g. the width at half-maximum height for the 110 reflection was $40^{\circ}$ (weak texture).

As mentioned earlier, a non-rotationally symmetric texture was observed in $\mathrm{HfAl}_{3}$ layers grown on hafnium substrates with a sheet texture. Figure 4 shows pole figures of some important reflections. The texture of the layers grown in $\mathrm{Hf}-\mathrm{Al}$ diffusion couples was always very weak near the $\mathrm{Al}-\mathrm{HfAl}_{3}$ interface. Nevertheless we found that the remaining texture near this interface always remained non-rotationally symmetric. The texture sharpness increased on going in the direction of the $\mathrm{HfAl}_{3}-\mathrm{Hf}$ interface. At a certain depth in the layer, which depended on the total thickness, the sharpness of the non-rotationally symmetric component reached a maximum. On proceeding to the $\mathrm{HfAl}_{3}-\mathrm{Hf}$ interface the texture became more rotationally symmetric. In fact the same texture component developed as was found in the $\mathrm{HfAl}_{3}$ layers grown on textureless hafnium, i.e. a [001] fan texture. This transition of the nonrotationally symmetric to the rotationally symmetric component took place 


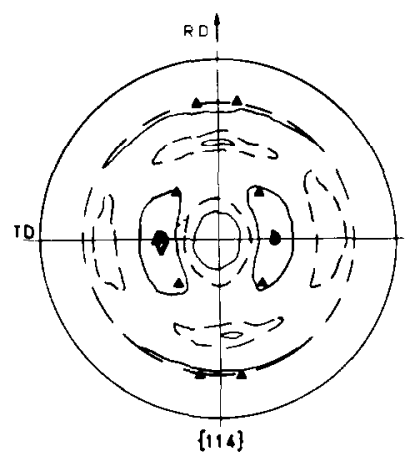

(a)

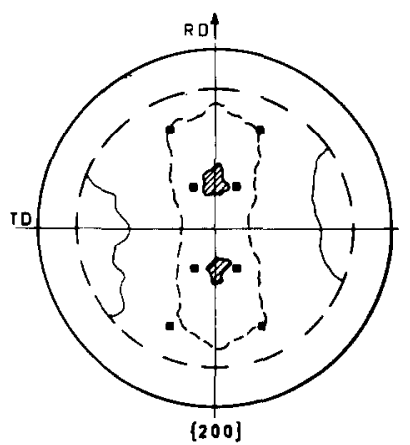

(b)

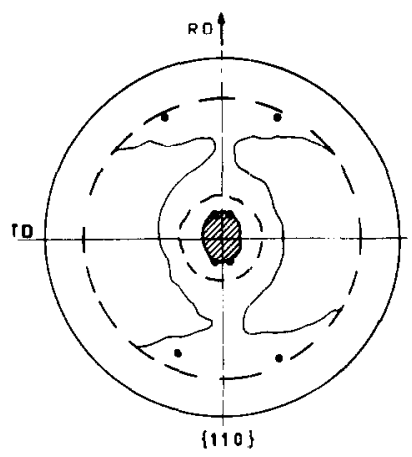

(c)

Fig. 4. Pole figures of $\mathrm{HfAl}_{3}$ diffusion layers grown on hafnium with a sheet texture: (a) 114 reflection; (b) 200 reflection; (c) 110 reflection.

gradually. It is important to note that at the same time a considerable increase in grain size occurred in the diffusion layer (Fig. 5). Moreover, the transition occurred more slowly at $595^{\circ} \mathrm{C}$ than at $640^{\circ} \mathrm{C}$.

$\mathrm{HfAl}_{3}$ layers grown on aluminium substrates via the iodine process also showed a texture. At $640^{\circ} \mathrm{C}$ the crystal growth was so fast that hardly any texture could be seen in the coarse-grained layers. After growth at $595^{\circ} \mathrm{C}$ the layer consisted of fine grains near the $\mathrm{HfAl}_{3}-\mathrm{Al}$ interface, and the grain size increased towards the $\mathrm{HfAl}_{3}$-vapour interface. A moderate-to-sharp rotationally symmetric texture was observed in the layer, with maximum sharpness at the $\mathrm{HfAl}_{3}$-vapour interface.

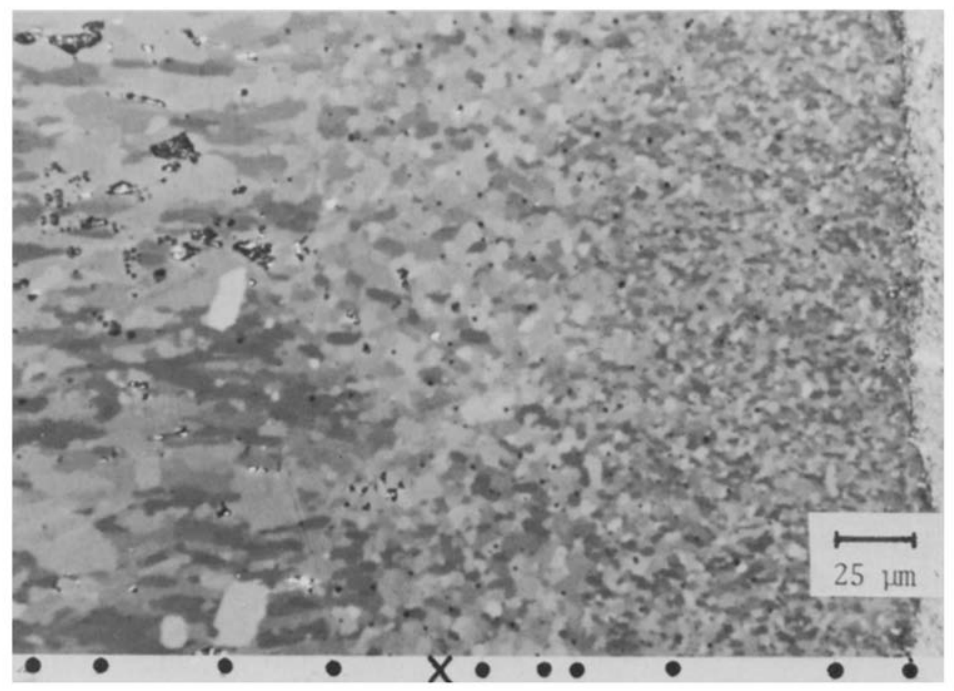

Fig. 5. Photomicrograph of an $\mathrm{HfAl}_{3}$ layer grown on hafnium with sheet texture $\left(41 \mathrm{~h}\right.$ at $\left.640^{\circ} \mathrm{C}\right)(\mathrm{left}$ hand side, $\mathrm{HfAl}_{3}-\mathrm{Hf}$ interface; right-hand side $\mathrm{HfAl}_{3}-\mathrm{Al}$ interface): $\bullet$, positions in the layer where the pole figures were measured; $x$, position where the maximum texture sharpness of the nonrotationally symmetric component is observed. 
TABLE 2

Measured and calculated tilt angles $\chi$ of the maxima of different reflections assuming an $\langle 841\rangle$ fibre texture in the $\mathrm{HfAl}_{3}$ layers

\begin{tabular}{llllll}
\hline$h k l$ & $\begin{array}{l}\chi_{\text {meas }} \\
(\mathrm{deg})\end{array}$ & $\begin{array}{l}\chi_{\text {calc }} \\
(\mathrm{deg})\end{array}$ & $h k l$ & $\begin{array}{l}\chi_{\text {meas }} \\
(\mathrm{deg})\end{array}$ & $\begin{array}{l}\chi_{\text {calc }} \\
(\mathrm{deg})\end{array}$ \\
\hline 004 & 65 & 64 & 103 & 26,55 & $25,55,66$ \\
101 & 30,55 & $28,47,61$ & 105 & 34,52 & $31,54,79$ \\
110 & $26,>70$ & 31,73 & 204 & 25,56 & $24,57,80$ \\
114 & $0^{*}, 63$ & $18,62,90$ & 211 & $0^{*}, 30^{\circ}$ & $18,32,55,61$ \\
200 & 35,63 & 36,66 & 215 & $0, \ldots$ & $2,33,47,53$ \\
& & & & $64,74,79$ \\
\hline
\end{tabular}

- Maxima very broad or absent owing to strong overlap.

The results of texture measurements show that no low index crystallographic axis can be considered as a fibre axis. The best correspondence between the calculated and the measured angles of the maxima was found for an $\langle 841\rangle$ direction parallel to the fibre axis (Table 2).

For completeness we mention that in the $\mathrm{HfAl}_{2}$ diffusion layers a sharp [0001] fan texture occurs. This compound has a hexagonal structure.

\section{Discussion of the results}

We first discuss the results obtained for $\mathrm{HfAl}_{3}$ layers grown on hafnium with a sheet texture. If the pole figure of the 114 reflection of $\mathrm{HfAl}_{3}$ (Fig. 4(a)) is compared with that of the 0002 reflection of hafnium (Fig. 2(b)), it can be seen that the positions of the maxima correspond. If the tetragonal cell of $\mathrm{HfAl}_{3}$ is approximated by four cubic subcells, i.e. $a=b=0.3989 \mathrm{~nm}$ and $c=1.7155 \mathrm{~nm}=4 \times 0.4289 \mathrm{~nm}$, the normal to the close-packed (114) plane can be considered as a [111] direction in the cubic lattice. In that case we expect the relation

$\mathrm{Hf}(0002) / / \mathrm{HfAl}_{3}(114)$

to exist. From the reciprocal lattices of hafnium and $\mathrm{HfAl}_{3}$ it can also be seen that a reasonable fit between the two lattices is possible in this way (Fig. 6 and Table 3). Therefore we conclude that the following orientation relation exists between hafnium and $\mathrm{HfAl}_{3}$ :

$\mathrm{Hf}(0002) / / \mathrm{HfAl}_{3}(114)$

$[11 \overline{2} 0]_{\mathrm{HI}} / /[\overline{8} 41]_{\mathrm{HIAl}_{3}}$

In the layers grown on aluminium substrates via the iodine process the $\langle 841\rangle$ direction again plays an important role (in the cubic subcell this would be a $\langle 211\rangle$ direction since $\left.a=b \approx \frac{1}{4} c\right)$. We therefore conclude that the first stage of the layer growth is epitaxial. 


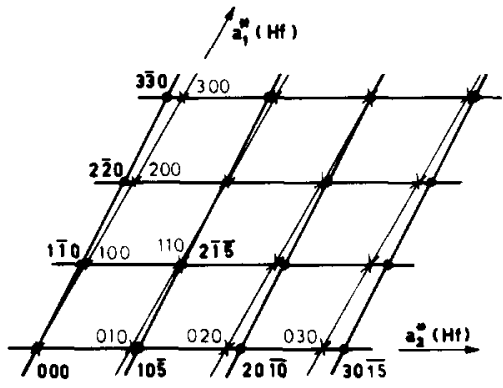

(a)

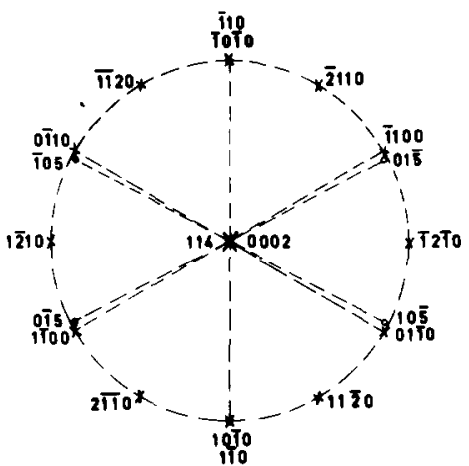

(b)

Fig. 6. (a) Superposition of the zero layers of the reciprocal lattices of hafnium (x) and $\mathrm{HfAl}_{3}(\bullet)$ (hafnium zone axis [0001]; $\mathrm{HfAl}_{3}$ zone axis [551]); (b) stereographic projection of hafnium $(x)$ and $\mathrm{HfAl}_{3}(\bullet)$ with their respective [0001] and [551] zones.

TABLE 3

Quantitative data for the orientation relations $\mathrm{Hf}(0002) / / \mathrm{HfAl}_{3}(114)$ and $[11 \overline{2} \mathrm{O}]_{\mathrm{Hr}} / /[\overline{8} 41]_{\mathrm{HrAl}_{3}}$

\begin{tabular}{ll}
$H f$ & $H f A l_{3}$ \\
\hline Angle between: & Angle between: \\
$(0002)$ and $(01 \overline{1} 0)=90.0^{\circ}$ & $(114)$ and $(10 \overline{\overline{5}})=91.8^{\circ}$ \\
$(0002)$ and $(\overline{1} 100)=90.0^{\circ}$ & $(114)$ and $(1 \overline{1} 0)=90.0^{\circ}$ \\
$(0002)$ and $(1 \overline{1} 0)=90.0^{\circ}$ & $(114)$ and $(2 \overline{1} \overline{\overline{5}})=88.9^{\circ}$ \\
$(01 \overline{1} 0)$ and $(\overline{1} 100)=60.0^{\circ}$ & $(10 \overline{5})$ and $(1 \overline{1} 0)=62.5^{\circ}$ \\
\hline
\end{tabular}

Misfits: $\quad\left(d_{\{100\}}-d_{\{105\}}\right) / d_{\{105\}}=+6.4 \% ; \quad\left(d_{\{100\}}-d_{\{110\}}\right) / d_{\{110\}}=-1.9 \% ; \quad\left(d_{\{110\}}-d_{\{215\}}\right) / d_{\{215\}}=$ $+1.0 \%$.

"The $[\overline{8} 41]$ direction is almost perpendicular to the $(2 \overline{1} \overline{5})$ plane.

However, the non-rotational texture component caused by the substrate texture is not stable. After some time (i.e. going in the direction of the $\mathrm{HfAl}_{3}-\mathrm{Al}$ interface) the texture sharpness decreases. On going to the $\mathrm{HfAl}_{3}-\mathrm{Hf}$ interface the new texture component is the same as that formed in $\mathrm{HfAl}_{3}$ layers on textureless hafnium substrates, i.e. the [001] fan texture. The transition from a sheet texture to a fan texture appears to be accompanied by a change in grain size and morphology (Fig. 5) and, at the same time, by a change in the growth kinetics of the layer (Fig. 1). If it is assumed that aluminium is the only diffusing species the reaction proceeds at the $\mathrm{Hf}-\mathrm{HfAl}_{3}$ interface. In this case the oldest part of the layer has apparently been formed in a very short time as indicated by the numerous small crystals present. The youngest part of the layer grows very slowly with the result that a few large crystals are formed.

F'igure 6 shows that the early stages of growth are dominated by an epitaxial mechanism. A volume diffusion process appears to dominate in the later stages, resulting in a fan texture. This gradual transition of the texture proceeds much more slowly at $595^{\circ} \mathrm{C}$ than at $640^{\circ} \mathrm{C}$, which again shows the importance of the large crystallites at the $\mathrm{HfAl}_{3}-\mathrm{Hf}$ interface. 


\section{Summarizing remarks}

$\mathrm{HfAl}_{3}$ layers grown between 550 and $640^{\circ} \mathrm{C}$ on textureless hafnium substrates show a [001] fan texture. This means that the $c$ axes of this tetragonal compound are preferentially orientated perpendicular to the direction of diffusion. A single-component sheet texture in the substrate can influence the texture in the diffusion-grown layer considerably, as shown for a hafnium substrate with a sheet texture. In this case a non-rotationally symmetric texture develops in the $\mathrm{HfAl}_{3}$ layer. This texture can be related to the texture in the hafnium substrate. If $\mathrm{HfAl}_{3}$ is grown from the vapour phase on aluminium substrates an $\langle 841\rangle$ fibre texture is observed.

\section{Acknowledgment}

This research was supported by the Netherlands Organization for the Advancement of Pure Research.

\section{References}

1 J. H. Maas and G. D. Rieck, High Temp. High Pressures, 10 (1978) 297.

2 M. Hansen and K. Anderko, Constitution of Binary Alloys, McGraw-Hill, New York, 1958.

3 R. P. Elliott, Constitution of Binary Alloys, McGraw-Hill, New York, 1st Suppl., 1965.

4 E. M. C. Huyser-Gerits and G. D. Rieck, J. Appl. Crystallogr., 7 (1974) 286.

5 J. R. Holland, Adv. X-Ray Anal., 7(1964) 86.

6 U. Kobbe and H. Schuon, Siemens-Z., 47 (1973) 119.

7 G. Wassermann and J. Grewen, Texturen Metallischer Werkstoffe, Springer, Berlin, 2nd edn., 1962. 